The Blacker the Ink 



\section{The Blacker the Ink}

Constructions of Black Identity in Comics and Sequential Art

EDITED BY FRANCES GATEWARD AND JOHN JENNINGS

Rutgers University Press 


\section{Library of Congress Cataloging-in-Publication Data}

The blacker the ink : constructions of black identity in comics and sequential art / edited by Frances Gateward and John Jennings.

pages $\mathrm{cm}$ Includes bibliographical references and index.

ISBN 978-0-8 I 35-7234-5 (hardcover : alk. paper)-ISBN 978-0-8 I 35-7233-8 (pbk. : alk. paper)-ISBN 978-0-8 1 35-7235-2 (epub)-ISBN (invalid) 978-0-81 355-7236-9 (web pdf) I. Comic books, strips, etc.-Social aspects-United States. 2. African Americans in literature. 3. African American cartoonists. I. Gateward, Frances K., editor. II. Jennings, John, I970- editor.

PN6725.B57 2015

$741.5^{\prime} 973-\mathrm{dc} 23$

2014035926

A British Cataloging-in-Publication record for this book is available from the British Library.

This collection copyright $\left(C_{20}\right.$ I 5 by Rutgers, The State University Individual chapters copyright $\odot 2015$ in the names of their authors

All rights reserved

No part of this book may be reproduced or utilized in any form or by any means, electronic or mechanical, or by any information storage and retrieval system, without written permission from the publisher. Please contact Rutgers University Press, 106 Somerset Street, New Brunswick, NJ 0890 I. The only exception to this prohibition is "fair use" as defined by U.S. copyright law.

Visit our website: http://rutgerspress.rutgers.edu

Manufactured in the United States of America 
This book is dedicated to the memory of Albert and Churie Thompson, Franklin Gateward, and Lee and Roz Desser. 
